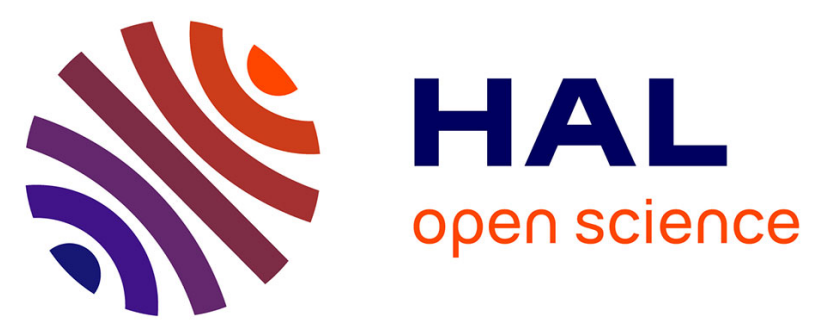

\title{
Homeosis and delayed floral meristem termination could account for abnormal flowers in cultivars of Delphinium (Ranunculaceae) and Aquilegia (Ranunculaceae) cultivars
}

Felipe Espinosa, Catherine Damerval, Martine Le Guilloux, Thierry Deroin, Wei Wang, Myreya Pinedo-Castro, Sophie Nadot, Florian P Jabbour

\section{To cite this version:}

Felipe Espinosa, Catherine Damerval, Martine Le Guilloux, Thierry Deroin, Wei Wang, et al.. Homeosis and delayed floral meristem termination could account for abnormal flowers in cultivars of Delphinium (Ranunculaceae) and Aquilegia (Ranunculaceae) cultivars. Botanical Journal of the Linnean Society, 2020, 10.1093/botlinnean/boaa063 . hal-02957360

\author{
HAL Id: hal-02957360 \\ https://hal.science/hal-02957360
}

Submitted on 27 Nov 2020

HAL is a multi-disciplinary open access archive for the deposit and dissemination of scientific research documents, whether they are published or not. The documents may come from teaching and research institutions in France or abroad, or from public or private research centers.
L'archive ouverte pluridisciplinaire HAL, est destinée au dépôt et à la diffusion de documents scientifiques de niveau recherche, publiés ou non, émanant des établissements d'enseignement et de recherche français ou étrangers, des laboratoires publics ou privés. 


\section{Homeosis and delayed floral meristem termination could account for abnormal}

flowers in Delphinium (Ranunculaceae) and Aquilegia (Ranunculaceae) cultivars

FELIPE ESPINOSA ${ }^{1,2}$, CATHERINE DAMERVAL ${ }^{3}$, MARTINE LE GUILLOUX $^{3}$, THIERRY DEROIN ${ }^{1}$, WEI WANG ${ }^{4,5}$, MYREYA PINEDO $^{6}$, SOPHIE NADOT $^{2}$, FLORIAN JABBOUR ${ }^{1}$

${ }^{1}$ Institut de Systématique, Évolution, Biodiversité (ISYEB), Muséum national d'Histoire naturelle, CNRS, Sorbonne Université, EPHE, Université des Antilles, Paris, France

${ }^{2}$ Université Paris-Saclay, CNRS, AgroParisTech, Ecologie Systématique Evolution, 91405, Orsay, France

${ }^{3}$ Génétique Quantitative et Evolution $(G Q E)$ - Le Moulon, Université Paris-Saclay, INRA, CNRS, AgroParisTech, Gif-sur-Yvette, France

${ }^{4}$ State Key Laboratory of Systematic and Evolutionary Botany, Institute of Botany, Chinese Academy of Sciences, Beijing, China

${ }^{5}$ University of Chinese Academy of Sciences, Beijing, China

${ }^{6}$ Laboratorio de Genética de Poblaciones Molecular-Biología Evolutiva, Departamento de Biología, Facultad de Ciencias, Pontificia Universidad Javeriana, Bogotá DC, Colombia

Running title: Dysfunctional floral meristems *Corresponding author. Address: Carrera 13 número 113-24, Bogota - Colombia; Telephone: (+571) 2159487; E-mail: felipeespinosam@gmail.com 


\begin{abstract}
Floral mutants display various deviant phenotypes and as such, they are an appropriate material to address the origin and the building of morphological variations. To identify the pivotal developmental stages at which floral variation may originate, and infer the putative associated genetic causes, we studied abnormal flowers in nine cultivars from Aquilegia and Delphinium of Ranunculaceae, a family displaying a high range of floral diversity. Wild-type flowers of the two genera are pentamerous and spurred but differ in their overall symmetry (actinomorphy vs. zygomorphy). Flower morphology of their cultivars at different developmental stages up to anthesis was observed and discussed the putative identity of the perianth organs and vascularization was inferred. Our results show that in the floral mutants from both genera, phyllotaxis was generally conserved while flower organization, vascularization, and symmetry were modified. Most of the morphological and anatomical deviations impacted the perianth, including organ number, identity, and (spur) elaboration, and also led to the formation of mosaic organs. We hypothesized that the phenotypes of Aquilegia and Delphinium floral mutants result from genetic alterations affecting frontiers between sets of organs of different identity, homeosis, and length of floral meristem activity.
\end{abstract}

ADDITIONAL KEYWORDS: development - homeosis - organ identity - perianth spurs - supernumerary organs. 


\section{INTRODUCTION}

The flower is considered as one of the major distinctive features of angiosperms (Endress, 1994; Rudall, 2013), the most diversified and successful plant group on Earth with more than $90 \%$ of living land plant species (ca. 300 000) (Stevens, 2001 onwards). While its groundplan is highly conserved, there is a wide diversity of floral traits (Endress, 1996). The number and form of floral organs, and their organization within the flower, have been shown to be linked to the pollination process and to the evolutionary success of the group (Friis, Chaloner \& Crane, 1989; Van der Niet \& Johnson, 2012).

Based on the study of floral mutants in two core eudicot species, Arabidopsis thaliana L. and Antirrhinum majus L., the identity of typical floral organs has been explained by a model composed of three main functions: A alone determines the sepals, $\mathrm{A}$ and $\mathrm{B}$ determine the petals, $\mathrm{B}$ and $\mathrm{C}$ the stamens and $\mathrm{C}$ the carpels (Coen \& Meyerowitz, 1991). Later, two additional functions have been uncovered: the E function interacts with all other functions and is responsible for floral identity (Honma \& Goto, 2001), and the D function has been unraveled in Petunia $\times$ hybrida E.Vilm. as controlling ovule identity (Colombo et al. 1995). These functions are carried out by transcription factors that mostly belong to the MADS-box family, which act as complexes - so-called floral quartets (Theißen \& Saedler 2001, Melzer \& Theißen, 2009). This model is broadly conserved at the level of angiosperms (Soltis et al., 2007; Rasmussen, Kramer \& Zimmer, 2009), and it has provided the framework for many evo-devo studies aiming at understanding the origin of floral diversity in the clade.

Ranunculales are sister to all other eudicots, the most species rich clade of angiosperms (APG IV, 2016), and is characterized by a large diversity in life history and floral morphology (Wang et al., 2009; Damerval \& Becker, 2017). Among the 
seven families recognized within Ranunculales, the buttercup family (Ranunculaceae) is the largest in terms of species number (ca. 2300 species in 62 genera) (Stevens, 2001) and hosts a high range of floral diversity. Since the $19^{\text {th }}$ century, the family has been subject to numerous morphological studies (e.g., Payer, 1857; Tamura, 1993; Kosuge, 1994; Utelli, Roy \& Baltisberger, 2000; Jabbour \& Renner, 2012a), several phylogenetic hypotheses have been produced (e.g., Cossard et al., 2016; Wang et al., 2016; Zhai et al., 2019), and more recently evo-devo studies have been conducted (Sharma et al., 2011; Gonçalves et al., 2013; Sharma \& Kramer, 2013; Zhang et al., 2013; Jabbour et al., 2014; Ballerini, Kramer, \& Hodges, 2019) providing a solid background to study the evolutionary mechanisms responsible for floral diversity of Ranunculceae. The perianth of Ranunculaceae presents an outstanding morphological diversity, in terms of number and form of organs. It can be composed of a single series of identical organs, or of two series of morphologically different organs, the inner series being usually nectariferous and highly modified in relation to the function of storing nectar (Hiepko, 1965; reviewed in Jabbour \& Renner (2012b). Following the most widely used terminology, in this study we named sepals and petals the outer and inner differentiated perianth organs in the wild types (WT), respectively.

Ever since the $17^{\text {th }}$ century, the study of deviant organisms that are very often perpetuated as horticultural varieties, has been playing a key role in understanding the biological mechanisms controlling floral development, organization and evolution (Clusius, 1601; Linnaeus, 1744; Goethe, 1790; Moquin-Tandon, 1841; Dupuy \& Guédès, 1980; Bateman \& Rudall, 2006; Sinjushin et al., 2015); for a review in Ranunculaceae see Jabbour et al. (2015a). In this study, we examine in detail floral development process in horticultural forms of the genera Delphinium L. and Aquilegia L. The two genera have been chosen because of their distant phylogenetic position 
within the family and contrast flower groundplans. Delphinium belongs to the tribe Delphinieae (subfamily Ranunculoideae) which is the sole clade of Ranunculaceae presenting zygomorphic flowers (Jabbour et al., 2009), while Aquilegia a model genus for evo-devo studies in Ranunculaceae (Kramer, 2009), belongs to the subfamily Thalictroideae. Based on the comparison between the WT floral morphology of Delphinium and Aquilegia and the mutant floral characteristics maintained by artificial selection of the horticultural forms, we propose hypotheses for the putative genetic bases underlying changes in the developmental sequence of mutant flowers. These hypotheses provide guidelines for future evo-devo investigations.

\section{MATERIALS AND METHODS}

\section{PLANT MATERIAL}

Young individuals were selected from five and four cultivars of Delphinium and Aquilegia, respectively, which were provided by the Jardin du Pic Vert (www.jardindupicvert.com). It is likely that all Delphinium cultivars result from crosses involving D. elatum L. (Duchartre, 1888; Legro, 1961; Cachon, 1982). Those of Aquilegia result from crosses involving A. vulgaris L. and A. viridiflora Pall. (Sims, 1809). The horticultural varieties were chosen according to 1) their availability in the catalogue of the horticulturist in November 2014 and 2) their diversity in floral morphology (Fig. 1), and especially in floral symmetry and the number of floral organs, including spurs.

For each cultivar, five plants presenting 3-4 leaves were installed in a growth chamber under long day period $\left(18-\mathrm{h}\right.$ day at $25^{\circ} \mathrm{C} / 6$-h night at $\left.16^{\circ} \mathrm{C}\right)$ until they reached the flowering phase. They were then transferred to a cold greenhouse. Inflorescences at various stages of development (from inflorescence initiation to anthesis) were sampled 
and fixed in FAA (90\% ethanol 70\%, 5\% formalin, 5\% acetic acid), and transferred to ethanol $70 \%$.

\section{FLORAL MORPHOLOGY AND ORGANIZATION}

Organ numbers were counted in 2-10 mature flowers depending on the cultivar.

Perianth organs were named with reference to the position and form of organs in WT flowers. Following the most widely used terminology, we name sepals and petals the outer and inner differentiated perianth organs in the wild types (WT), respectively. For example, in A. vulgaris 'Leprechaun Gold' supernumerary spurred organs are called petals, while in A. vulgaris 'Nora Barlow' supernumerary flat organs are called sepals. Organs mixing characters of two or more types of organs were called mosaic organs. One adult flower of each cultivar was selected and dissected under a stereomicroscope (Nikon SMZ 745T). The organs were mounted on a sheet of paper following phyllotaxis and deposited at the Paris Herbarium (P04023431-P04023436 and P04023438P04023440, accessible using the link:

https://science.mnhn.fr/institution/mnhn/collection/p/item/search). Additionally, at least one herbarium specimen was made for each cultivar and deposited in P (P04021840P04021855; Table S1 in Supplementary Material).

Fixed buds covering all the developmental phases were dissected using the same stereomicroscope from a single cultivar of each genus (namely $D . \times$ Pacific 'Blue Jay' and $A$. vulgaris 'Leprechaun Gold'). They were dehydrated in an ethanol series $(70 \%$, 80\%, absolute alcohol) and dried using an Emitech K850 critical-point dryer (Quorum Technologies), mounted on aluminum stubs with colloidal graphite, sputter-coated with gold during $60 \mathrm{~s}$ using a JFC-1200 fine coater (JEOL), and observed using an SU3500 Scanning Electron Microscope (Hitachi). 


\section{FLORAL ANATOMY}

A preanthetic floral bud from a single cultivar of each genus was sampled (namely $D . \times$ Pacific 'Blue Jay' and A. vulgaris 'Leprechaun Gold') to study floral organ vascularization using a classic protocol to investigate plant anatomy. Buds were dehydrated through a t-butyl series and embedded in paraffin (melting point: $58-60^{\circ} \mathrm{C}$; (Gerlach, 1984)). Serial transverse sections were cut at a thickness of $12 \mu \mathrm{m}$ using a rotary microtome Leitz 1512, and stained with Astra Blue 0.5\% aqueous (Chroma 1B163) and Ziehl's fuchsine 10\%. The material was mounted and observed using a Nikon Eclipse Ci microscope. Floral vascularization was reconstructed by drawing selected serial cross sections using a camera lucida. Cross sections of buds did not allow observing the morphology of the inner perianth organs, hence precluding any inference about their identity. Mountings are deposited in the Paris Herbarium microscopical slide library.

\section{RESULTS}

MORPHOLOGY AND ANATOMY OF DELPHINIUM FLORAL CULTIVARS AS COMPARED WITH

\section{WILD TYPE}

The WT flower of D. elatum reflects the general description for the genus. Five petaloid sepals are initiated on a spiral and quincuncially overlapping: two ventral (number 1 and 3 in the sequence of the ontogenic spiral) and two lateral sepals (number 4 and 5), and a spurred dorsal one (number 2). Four sessile petals are located in the dorsal half of the flower: two in dorsal position and two in dorso-lateral position. Four primordia in the ventral half of the flower stop developing shortly after initiation (Payer, 1857). The two dorsal petals are nectariferous structures forming spurs enclosed in the spur of the dorsal 
sepal. The other two dorso-lateral petals are generally exsert, flat and epeltate (Schrödinger, 1909; Blanché, 1990; Tamura, 1993; Jabbour \& Renner, 2012a). The androecium is composed of numerous stamens (26-31, counted in nine flowers), and the gynoecium of three (the specimen studied here) to five free carpels (Tamura, 1993). All floral organs are spirally inserted.

The perianth of $D . \times$ Pacific 'Blue Jay' was composed of 17-23 spirally inserted organs, the outer ones having a quincuncial aestivation (Fig. 2A and Fig. 3A, Table S1in Supplementary Material). The anthetic flowers showed the full range of calyx diversity found in Delphinium cultivars. Sepals (12-17) were oblong to obovate with an acute to obtuse apex (Fig. 2A). One flower had a peloric (actinomorphic, spurless) calyx, with a corolla also peloric, consisting of flat petals morphologically similar to WT dorsolateral petals. It was the only flower to present these characteristics and it occupied an intermediate position in the inflorescence. In the other cases, flowers had a zygomorphic calyx. Flowers that had a single spur on the dorsalmost sepal had a spurless and radialized corolla, while the flower with two nested spurs on dorsal sepals had a zygomorphic corolla with a single dorsal spurred petal. Mosaic organs presenting features of both petals and stamens or stamens and carpels were found surrounding the carpels or surrounding the androecium respectively (Fig. 4).

The different combinations of character states that were observed in flowers of all the varieties investigated are summarized in Figure 5 (A, C; see Table S1 in Supplementary Material for the original counts). Overall, phyllotaxis was spiral and zygomorphy was conserved except in the single flower of $D . \times$ Pacific 'Blue Jay' where the calyx and corolla were spurless. In one flower of $D . \times$ Pacific 'Astolat', a spurred dorsal petal was observed while no spurs were found in the calyx. The petals in the 
ventral half of the corolla were fully developed in most cases (but see Fig. 6F). Petalstamen mosaic organs were often observed surrounding the androecium (Fig. 4 D2). These organs presented a filament, pollen sac-like structures and an oblate outgrowth fixed along the filament or in other cases unclosed winged structures with an oblate outgrowth (as shown in Fig. 4D1). Except for one flower of $D . \times$ Pacific 'Guinevere' being identical to WT and found in an inflorescence with abnormal flowers, flowers from the Delphinium cultivars had a total organ number of 53-63 (38-45 in WT), and the increase in organ number affected each of the four organ types (sepals, petals, stamens and carpels) (Fig. 2A). In the cultivars we studied, single plants exhibited neither a set of flowers with strictly identical morphologies and organizations, nor any regularity of the distribution of flowers with similar anomalies within an inflorescence.

Outermost sepal organs of the perianth in $D . \times$ Pacific 'Blue Jay' were supplied by two vascular bundles, except for the dorsal organ supplied by three independent vascular bundles. The two ventral and four lateral (two on the right side and two on the left side) inner organs were supplied by two vascular bundles each, and the two dorsal and spurred organs were supplied by a single vascular bundle each. Each of the innermost organs of the perianth was supplied by a single vascular bundle. Stamens were supplied by a single vascular bundle, and three independent bundles (Fig. 3B-E and K) supplied each carpel.

Although the additional sepals, spirally arranged between the first five sepals and the corolla, had a sepal morphology, they presented some variations: first, the colour of these organs varied between the colour of sepals (blue, lilac or white) and petals (stramineous to white or black, in some cases, the inner organs was white with some brush-strokes of black or stramineous, Fig. 1). Second, the additional sepals presented a morphological gradient between sepal and petal morphology, ranging from 
outer oblong or obovate organs with an acute apex to thinner and spatulate inner organs (Fig. 2A). Third, the vascularization of the additional sepals differed from WT perianth organs: the dorsalmost one presented a single vascular bundle and the others presented two vascular bundles (Fig. 3B-C), while WT sepals was supplied with three bundles and WT petals was all supplied with a single bundle (Novikoff \& Jabbour, 2014).

FLORAL MORPHOLOGY AND ANATOMY OF THE AQUILEGIA CULTIVARS AS COMPARED WITH WILD TYPE

The floral groundplan of Aquilegia is well conserved between species, the most variable character being the stamen number. The flower is actinomorphic and composed of five pentamerous categories of organs: two types of petaloid organs forming the perianth, stamens, a whorl of staminodes, and carpels. Sepals are ovate organs with an acute apex and quincuncially overlapping. The five petals are arranged on a whorl and are sessile, spurred, nectariferous, and alternate with the sepals. The androecium is composed of stamens arranged in 10 orthostichies of four to six whorls and is topped with a whorl of staminodes. The gynoecium usually includes five free carpels (Payer, 1857; Van Heel, 1981; Tucker \& Hodges, 2005).

The anthetic flowers of $A$. vulgaris 'Leprechaun Gold' had a calyx composed of 4-5 sepals, and a corolla of 11-26 spurred petals (Table S1, Fig. 5F). The androecium comprised fewer stamens (26-44) than the WT (40-60). Ten or no staminodes, and five carpels were observed. Whorls of petals, stamens and staminodes formed orthostichies, and the gynoecium was also whorled. A few petal-stamen mosaic organs were found around the androecium (as shown in Figs. 2B and 7).

Many flowers from the other Aquilegia cultivars investigated had a calyx with 7-43 additional sepals, initiated in whorls. Corolla was either absent or consisted of 18- 
30 petals. The corolla was occasionally absent within cultivars $A . \times$ hybrida 'Ruby Port' and 'Green Apples', while it was consistently absent in flowers of $A$. vulgaris 'Nora Barlow' (Fig. 5F, Table S1 in Supplementary Material). The androecium generally comprised fewer stamens (33-49) than the WT. Nine to 15 staminodes, and 4-7 carpels were observed. Petal-stamen (Fig. 7) and stamen-staminode mosaic organs were occasionally found around the androecium and around the whorl of staminodes, respectively.

In a single flower from $A . \times$ hybrida 'Ruby Port', we observed an increase in both sepal and petal numbers: the calyx was composed of 5 spirally inserted sepals and 7 additional sepals arranged in a whorl, and the corolla was composed of 25 petals. This flower had four carpels but was devoid of both stamens and staminodes. Moreover, in a single flower of $A$. $\times$ hybrida 'Green Apples', a stamen-carpel mosaic organ was observed between the whorl of staminodes and the gynoecium.

It has to be noted that in the only cases where stamen-staminode and stamen-carpel mosaic organs were observed (in A. × hybrida 'Green Apples'), the flowers had no petals but petal-stamen mosaic organs instead (Fig. 9).

In A. vulgaris 'Leprechaun Gold' cultivar flower, sepals were supplied by three independent vascular bundles. The five outermost petals were supplied by one vascular bundle that ramified in three bundles at the basis of the organ, and the subsequent petal whorls also had a trifid vascular bundle, formed by the union of two ramifications derived from the bundles of the nearest external whorl. Each stamen and each staminode was supplied by a single vascular bundle and each carpel was supplied by three independent vascular bundles (Fig. 3G-J and L).

\section{DISCUSSION}


In comparison with the respective wild-type species from which they are derived, the cultivars of Delphinium and Aquilegia analyzed in this study presented floral variations mostly affecting the perianth, in terms of the number and/or identity of the organs. The number of stamens and carpels was affected as well, but in a different way: Delphinium cultivars presented more stamens and carpels than the typical flowers of D. elatum, and Aquilegia cultivars presented fewer stamens than the typical flowers of both $A$. vulgaris and A. viridiflora (Fig. 5, Table S1 in Supplementary Material). Altogether, these modifications produce the remarkable double flowers selected by horticulturalists. Our study highlights the occurrence of mosaic organs presenting mixed characteristics of corolla, androecium and gynoecium (Figs. 4 and 7). Additionally, major floral phenotypic variation within plants from the same cultivar was observed, indicating that floral characteristics within cultivars are not fixed.

\section{SUPERNUMERARY ORGANS IN DELPHINIUM: DELAYED FLORAL MERISTEM TERMINATION?}

Among the five Delphinium cultivars analyzed, all flowers except one of them (hence 18) presented more organs from each of the four WT morphological types of organs (sepals, petals, stamens and carpels) than the typical D. elatum flowers. Spiral phyllotaxis is conserved in all mutant flowers. Our hypothesis is that the formation of supernumerary organs/primordia on the whole surface of the meristem might be due to a prolonged meristematic activity and/or an enlarged floral meristem compared to the WT. The gene network responsible for floral meristem termination has been partially decrypted in $A$. thaliana (Xu et al., 2019), revealing a crucial role of the AGAMOUS $(A G)$ gene in floral meristem termination in addition to its role in organ identity as a $\mathrm{C}$ function gene. $A G$ finally represses the WUSCHEL gene that is responsible for stem cell identity and maintenance (Lenhard et al., 2001). Any mutation lowering $A G$ level of 
expression can entail delayed floral meristem termination, resulting in an increase in organ number without affecting their identity (Sieburth, Running \& Meyerowitz, 1995). Two paralogous $A G$ lineages have been described in Ranunculaceae (Kramer, Jaramillo \& Di Stilio, 2004). Expression data suggest some subfunctionalization of the paralogs, one being more expressed in the stamens, the other one in the gynoecium (Di Stilio, Kramer \& Baum, 2005; Jabbour et al., 2015b; Wang et al., 2015). The expression of these paralogs, possibly the carpel-specific one (if both have been kept in Delphinium), could be reduced in the cultivars studied here. Homolog of the SUPERMAN gene could be another candidate, based on its role in floral meristem size and termination partly independent from $A G$ in $A$. thaliana (Xu et al., 2019).

\section{FEWER STAMENS AND MORE PERIANTH ORGANS IN AQUILEGIA: HOMEOSIS?}

The flowers of all Aquilegia cultivars had a total number of organs falling in the upper range of what is usually recorded for the WT (Payer, 1857; Van Heel, 1981; Tucker \& Hodges, 2005). The comparison of organ number among organ types reveals that the increase in perianth organ number is at the expense of the stamens, suggesting homeosis as the main cause of the phenotypes observed. Staminodes, which have a close affinity with stamens based on developmental studies (Tucker \& Hodges, 2005; Kramer et al., 2007; Sharma \& Kramer, 2013), seem to be unaffected since their number is similar or occasionally increased compared to the WT. We highlight the fact that phyllotaxis is conserved in the mutant flowers: sepals are spirally inserted, and the remaining floral organs was arranged in whorls (Fig. 8). Importantly, when present, the additional sepals are arranged in whorls. It could indicate that the transition between spiral and whorled phyllotaxis is determined in an identical way in WT and mutant flowers, no matter the identity of the first organs being initiated on a whorl. In other Ranunculales species, 
such as Actaea rubra (Aiton) Willd. (Ranunculaceae) and Circaeaster agrestis Maxim. (Circaeasteraceae), reports of organ number variations due to homeosis and affecting the basic structure of the flower have been made (Lehmann \& Sattler, 1994; Tian et al., 2007). Unlike these cases, the WT floral groundplan is maintained in the horticultural flowers of Aquilegia.

Anatomically, the supernumerary petals of A. vulgaris 'Leprechaun Gold' present the same vascularization as WT petals (Fig. 3H; (Eames, 1931; Tepfer, 1953)). However, and in contrast with WT vascularization, the origin of the traces creates a complex network, where each bundle supplying the internal whorls of petals in the mutant flower studied is the union of two ramifications derived from the bundles of the nearest external whorl (Fig. 3H).

Our observations suggest that homeosis in Aquilegia is expressed under two forms. In one form, stamens are replaced by petals, which is observed in A. vulgaris 'Leprechaun Gold' and A. × hybrida 'Ruby Port', and some flowers of $A . \times$ hybrida 'Green Apples', with variation in the number of stamens replaced. In the other form, observed in most flowers of $A . \times$ hybrida 'Green Apples' and A. vulgaris 'Nora Barlow', petal identity disappears at the expense of sepals, with a probable homeotic conversion of some outer stamens into sepals. One flower in $A . \times$ hybrida 'Ruby Port' combines both phenomena and is totally deprived of stamens and staminodes. In Aquilegia and other Ranunculaceae, the B-function APETALA3-3 (AP3-3) genes have been shown to be responsible for petal identity (Sharma et al., 2011; Gonçalves et al., 2013; Wang et al., 2015). We may thus hypothesize that variation in the expression domain of this gene, possibly at the expense of C-function genes, could account for our observations. Indeed, limitations of the $A G$ expression have been noticed in double flower phenotypes of various species (Dubois et al., 2010; Lui et al. 2013; Sun et al. 
2014; Akita, Horikawa \& Kanno, 2008; Akita, Nakada \& Kanno, 2011; François et al., 2018). Phenotypes without petals have been described in Aquilegia coerulea E.James and N. damascena L. (Sharma et al., 2011; Gonçalves et al., 2013) and in both cases they have been shown to be caused by the inactivation of AP3-3 genes (Kramer, Di Stilio \& Schlüter, 2003; Gonçalves et al., 2013; Zhang et al., 2013). In N. damascena, the absence of expression of the NdAP3-3 gene appears correlated with both genetic and morphological facts: there is an extension of the expression domain of both $N d A G$ paralogs in the additional sepals, as well as the presence of organs with a mixed identity between the additional sepals and stamens (Jabbour et al., 2015b). Such mechanism could be involved in the cultivars $A$. vulgaris 'Nora Barlow' or $A$. $\times$ hybrida 'Green Apples', where we observed up to 12 organs with a mosaic sepal-stamen identity.

However, it must be underlined that the total number of sepals is large, especially in $A . \times$ hybrida 'Green Apples', suggesting that supernumerary organs are also present, and could originate through delayed floral meristem termination or increased floral meristem size, as in Delphinium cultivars.

\section{ORGANS OF MOSAIC IDENTITY}

In Delphinium and Aquilegia cultivars, organs of mosaic identity between perianth and reproductive organs have been noticed (Figs. 2, 4, 7 and 9). These observations suggest fluctuations in the extension of the expression domains of genes involved in A-, B- and C-functions, resulting in fuzzy boundaries. In Arabidopsis, several genes have been shown to play a floral cadastral role, restraining B- and C- function genes to the center of the flower thus enabling a distinct perianth to be formed (Monniaux \& Vandenbussche, 2018). However, no homologs of these genes have been characterized in Ranunculaceae yet. The expression domain of B-function genes may play an 
important role in the phenomenon we observed. For example, in two horticultural varieties of water lily (Nymphaea), the B-function genes $A P 3$ and $P I$, usually highly expressed in pure petals and stamens, showed a lower expression level in the intermediary whorls, giving rise to floral organs showing characteristics of both petals and stamens (Luo et al. 2011). The expression of B-function genes has been shown to be important for the maintenance of the outer extension of the $\mathrm{C}$-function domain at least in Aquilegia and Nigella L., as well as in Eschscholzia Cham., a member of Papaveraceae, another family of the Ranunculales (Sharma \& Kramer, 2017).

\section{FLORAL SYMMETRY IN DELPHINIUM MUTANT FLOWERS}

Zygomorphy in floral cultivars of Delphinium can be affected by changes in spur number (from none to several) in the calyx and in the corolla, and to the ventral reduction of the corolla. In a few cases where spurs are found in sepals, spurs are lacking in petals. There is a single case where a spur is observed in a dorsal petal without spurs in dorsal sepals. (Fig. 5F, Table S1 in Supplementary Material). These observations suggest that the morphogenetic signals directing the formation of spurs in the dorsal region are at least partly dependent upon organ identity, viz. sepal or petal. The corolla is fully developed in most of the mutant flowers (as shown for example in Fig. 2A), but it may be of interest that in the two flowers where it is not fully developed, spurs are present in both dorsal sepals and petals. This observation suggests that the presence of spurs in the full perianth dorsal region could be necessary but not sufficient for growth repression in the corolla ventral region. The degree of peloria is hence variable, depending on the presence or absence of the dorsal spur(s) in the calyx and corolla, and on the degree of corolla reduction (partial to no reduction). The role of the CYCLOIDEA-like (CYC-like) transcription factor genes in the establishment of 
zygomorphy has been shown in several taxa (Luo et al., 1996, Hileman 2014 for review). An asymmetric expression of $C Y C$-like genes correlated to dorso-ventral asymmetry has been observed in sepals of Aconitum carmichaelii Debeaux and Consolida regalis Gray (Jabbour et al., 2014). More detailed studies are necessary to examine whether genes of this family could play some role in floral symmetry in these species.

Horticultural cultivars result from human selection aiming at enhancing showy floral characteristics. Delphinium and Aquilegia cultivars present double flowers with alterations in the number and position of nectariferous spurred structures, and a visual modification of the floral symmetry with a tendency to actinomorphy in Delphinium. In addition, these mechanisms would be associated with alterations in the floral meristem termination in Delphinium cultivars and with homeosis in Aquilegia cultivars.

\section{ACKNOWLEDGEMENTS}

We thank the Institut de Systématique Evolution Biodiversité for financial support and the staff from Paris herbarium and the 'Direction des Collections' (Muséum national d'Histoire naturelle $[\mathrm{MNHN}]$ ) for providing the material for the anatomical study. We acknowledge the 'Plateforme de microscopie électronique' (MNHN) where the SEM study was conducted, and we thank Géraldine Toutirais for her assistance during the SEM sessions. We thank Valéry Malécot for a discussion about the likely process of human selection having led to the cultivars studied in this paper. Financial support for Felipe Espinosa's $\mathrm{PhD}$ was provided by the Colombian government agency Colciencias. We thank Dmitry Sokoloff and two anonymous reviewers for their comments and invaluable suggestions that greatly improve our manuscript. 


\section{REFERENCES}

Akita Y, Horikawa Y, Kanno A. 2008. Comparative analysis of floral MADS-box genes between wild type and putative homeotic mutant, in lily. The Journal of Horticultural Science and Biotechnology 83: 437-443.

Akita Y, Nakada M, Kanno A. 2011. Effect of the expression level of an AGAMOUSlike gene on the petaloidy of stamens in the double-flowered lily, 'Elody'. Scientia Horticulturae 128: 48-53.

APG IV. 2016. An update of the Angiosperm Phylogeny Group classification for the orders and families of flowering plants: APG IV. Botanical Journal of the Linnean Society 181: 1-20.

Ballerini ES, Kramer EM, Hodges SA. 2019. Comparative transcriptomics of early petal development across four diverse species of Aquilegia reveal few genes consistently associated with nectar spur development. BMC Genomics 20: 668. Bateman RM, Rudall PJ. 2006. The good, the bad and the ugly: Using naturally occurring terata to distinguish the possible from the impossible in the orchid floral evolution. Aliso 22: 481-496.

Blanché C. 1990. Delphinium L. subgen. Delphinium: origin and evolutionary trends. Collectanea Botanica 19: 75-95.

Cachon H. 1982. Problèmes de sélection chez Delphinium hybridum L. : stérilité mâle et résistance de la tige à la verse. Agronomie 2: 819-828.

Clusius C. 1601. Rariorum plantarum historia. Antverpiae: Ex officina Plantiniana Apud Ionannem Moretum.

Coen ES, Meyerowitz EM. 1991. The war of the whorls: genetic interactions controlling flower development. Nature 353: 31-37. 
Colombo L, Franken J, Koetje E, van Went J, Dons HJM, Angenent GC, Van

Tunen AJ. 1995. The Petunia MADS box gene FBP11 determines ovule identity. The Plant Cell 7: 1859-1868.

\section{Cossard G, Sannier J, Sauquet H, Damerval C, de Craene LR, Jabbour F, Nadot}

S. 2016. Subfamilial and tribal relationships of Ranunculaceae: evidence from eight molecular markers. Plant Systematics and Evolution 302: 419-431.

Damerval C, Becker A. 2017. Genetics of flower development in Ranunculales - a new, basal eudicot model order for studying flower evolution. New Phytologist 216: $361-366$.

Di Stilio VS, Kramer EM, Baum DA. 2005. Floral MADS box genes and homeotic gender dimorphism in Thalictrum dioicum (Ranunculaceae) - a new model for the study of dioecy. The Plant Journal 41: 755-766.

Dubois A, Raymond O, Maene M, Baudino S, Langlade NB, Boltz V, Vergne P, Bendahmane M. 2010. Tinkering with the C-function: a molecular frame for the selection of double flowers in cultivated roses. PLoS One 5: e9288.

Duchartre M. 1888. Organisation de la fleur dans des variétés cultivées du Delphinium elatum L. Bulletin de la Société Botanique de France 35: 85-98.

Dupuy P, Guédès M. 1980. Documents tératologiques pour servir à l'étude morphologique des Angiospermes. Bulletin du Muséum national d'Histoire naturelle 2: $83-144$.

Eames AJ. 1931. The vascular anatomy of the flower with refutation of the theory of carpel polymorphism. American Journal of Botany 18: 147-188.

Endress PK. 1994. Floral structure and evolution of primitive angiosperms: recent advances. Plant Systematics and Evolution 192: 79-97.

Endress PK. 1996. Diversity and evolutionary biology of tropical flowers. Cambridge: 
Cambridge University Press.

Erbar C, Kusma S, Leins P. 1999. Development and interpretation of nectary organs in Ranunculaceae. Flora 194: 317-332.

François L, Verdenaud M, Fu X, Ruleman D, Dubois A, Vandenbussche M, Bendahmane A, Raymond O, Just J, Bendahmane M. 2018. A miR172 targetdeficient AP2-like gene correlates with the double flower phenotype in roses. Scientific Reports 8: 12912.

Friis EM, Chaloner FRS WG, Crane PR. 1989. The origins of angiosperms and their biological consequences. Cambridge: Cambridge University Press.

Gerlach D. 1984. Botanische Mikrotechnik. Stuttgart: Thieme.

Goethe JW Von. 1790. Versuch die Metamorphose der Pflanzen zu erklären. Germany: CW Ettinger.

Gonçalves B, Nougué O, Jabbour F, Ridel C, Morin H, Laufs P, Manicacci D, Damerval C. 2013. An APETALA3 homolog controls both petal identity and floral meristem patterning in Nigella damascena L. (Ranunculaceae). The Plant Journal 76: $223-235$.

Hiepko P. 1965. Vergleichend-morphologische und entwicklungsgeschichtliche Untersuchungen über das Perianth bei den Polycarpicae. Botanische Jahrbücher für Systematik 84: 359-508.

Hileman LC. 2014. Bilateral flower symmetry - how, when and why? Current Opinion in Plant Biology 17: 146-152.

Honma T, Goto K. 2001. Complexes of MADS-box proteins are sufficient to convert leaves into floral organs. Nature 409: 525-529.

Jabbour F, Ronse De Craene LP, Nadot S, \& Damerval C. 2009. Establishment of zygomorphy on an ontogenic spiral and evolution of perianth in the tribe Delphinieae 
(Ranunculaceae). Annals of Botany 104: 809-822.

Jabbour F, Cossard G, Le Guilloux M, Sannier J, Nadot S, Damerval C. 2014.

Specific duplication and dorsoventrally asymmetric expression patterns of Cycloidealike genes in zygomorphic species of Ranunculaceae. PLoS ONE 9: e95727.

Jabbour F, Nadot S, Espinosa F, Damerval C. 2015a. Ranunculacean flower terata: Records, a classification, and some clues about floral developmental genetics and evolution. Flora 217: 64-74.

Jabbour F, Udron M, Le Guilloux M, Gonçalves B, Manicacci D, Nadot S, Damerval C. 2015b. Flower development schedule and AGAMOUS-like gene expression patterns in two morphs of Nigella damascena (Ranunculaceae) differing in floral architecture. Botanical Journal of the Linnean Society 178: 608-619.

Jabbour F, Renner SS. 2012a. A phylogeny of Delphinieae (Ranunculaceae) shows that Aconitum is nested within Delphinium and that Late Miocene transitions to long life cycles in the Himalayas and Southwest China coincide with bursts in diversification. Molecular Phylogenetics and Evolution 62: 928-942.

Jabbour F, Renner SS. 2012b. Spurs in a spur: perianth evolution in the Delphinieae (Ranunculaceae). International Journal of Plant Sciences 173: 1036-1054.

Kosuge K. 1994. Petal evolution in Ranunculaceae. Plant Systematics and Evolution 8: $185-191$.

Kramer EM. 2009. Aquilegia: A new model for plant development, ecology, and evolution. Annual Review of Plant Biology 60: 261-277.

Kramer EM, Di Stilio VS, Schlüter PM. 2003. Complex patterns of gene duplication in the APETALA3 and PISTILLATA lineages of the Ranunculaceae. International Journal of Plant Sciences 164: 1-11.

Kramer EM, Holappa L, Gould B, Jaramillo MA, Setnikov D. Santiago PM. 2007. 
Elaboration of B gene function to include the identity of novel floral organs in the lower eudicot Aquilegia. The Plant Cell 19: 750-766.

Kramer EM, Jaramillo MA, Di Stilio VS. 2004. Patterns of gene duplication and functional evolution during the diversification of the AGAMOUS Subfamily of MADS box genes in angiospermes. Genetics 166: 1011-1023.

Legro RAH. 1961. Species hybrids in Delphinium. Euphytica 10: 1-23.

Lehmann NL, Sattler R. 1994. Floral development and homeosis in Actaea rubra (Ranunculaceae). International Journal of Plant Sciences 155: 658-671.

Lenhard M, Bohnert, Jürgens G, Laux T. 2001. Termination of stem cell maintenance in Arabidopsis floral meristems by interactions between WUSCHEL and AGAMOUS. Cell 105: 805-814.

Linnaeus C. 1744. Dissertatio Botanica de Peloria. Uppsala: Amoenitates Academica. Lui Z, Zhang D, Liu D, Li F, Lu H. 2013. Exon skipping of $A G A M O U S$ homolog Prse AG in developing double flowers of Prunus lannesiana (Rosaceae). Plant Cell Reports 32: 227-237.

Luo D, Carpenter R, Vincent C, Copsey L, Coen E. 1996. Origin of floral asymmetry in Antirrhinum. Nature 383: 794-799.

Luo H, Chen S, Jiang J, Chen Y, Chen F, Teng N, Yin D, Huang, C. 2011. The expression of floral organ identity genes in contrasting water lily cultivars. Plant Cell Reports. 30: 1909-1918.

Melzer R, Theißen G. 2009. Reconstitution of 'floral quartets' in vitro involving class B and class E floral homeotic proteins. Nucleic Acids Research 37: 2723-2736.

Moquin-Tandon A. 1841. Eléments de tératologie végétale, ou histoire abrégée des anomalies de l'organisation dans les végétaux. Paris: P.-J. Loss.

Monniaux M, Vandenbussche M. 2018. How to evolve a perianth: A review of 
cadastral mechanisms for perianth identity. Frontiers in Plant Science. 9: 1573.

Novikoff A, Jabbour F. 2014. Floral anatomy of Delphinieae (Ranunculaceae):

Comparing flower organization and vascular patterns. Modern Phytomorphology 5: 35-

44.

Payer J. 1857. Traité d'organogénie comparée de la fleur. Paris: Masson.

Rasmussen DA, Kramer EM, Zimmer EA. 2009. One size fits all? Molecular evidence for a commonly inherited petal identity program in Ranunculales. American Journal of Botany 96: 96-109.

Rudall PJ. 2013. Identifying key features in the origin and early diversification of angiosperms. Annual Plant Reviews 45: 163-188.

Schrödinger R. 1909. Der Blütenbau der zygomorphen Ranunculaceen und seine Bedeutung für die Stammesgeschichte der Helleboreen. Abhandlungen der kaiserlichkoniglichen zoologisch-botanischen Gesellschaft in Wien 4: 1-63.

Sharma B, Guo C, Kong H, Kramer EM. 2011. Petal-specific subfunctionalization of an $A P E T A L A 3$ paralog in the Ranunculales and its implications for petal evolution. New Phytologist 191: 870-883.

Sharma B, Kramer E. 2013. Sub- and neo-functionalization of APETALA3 paralogs have contributed to the evolution of novel floral organ identity in Aquilegia (columbine, Ranunculaceae). New Phytologist 197: 949-957.

Sharma B, Kramer EM. 2017. Aquilegia B gene homologs promote petaloidy of the sepals and maintenance of the $\mathrm{C}$ domain boundary. EvoDevo 8: 22.

Sieburth LE, Running MP, Meyerowitz EM. 1995. Genetic separation of third and fourth whorl functions of AGAMOUS. The Plant Cell 7: 1249-1258.

Sims J. 1809. Aquilegia hybrida. Two-coloured columbine. Curtis' Botanical Magazine 30: $1220-1222$. 
Sinjushin AA, Bagheri A, Maassoumi AA, Rahiminejad MR. 2015. Terata of two legume species with radialized corolla: some correlations in floral symmetry. Plant Systematics and Evolution 301: 2387-2397.

Soltis DE, Chanderbali AS, Kim S, Buzgo M, Soltis PS. 2007. The ABC model and its applicability to basal angiosperms. Annals of Botany 100: 155-163.

Stevens PF. 2001 onwards. Angiosperm phylogeny website. Version 14, July 2017 [and more or less continuously updated since]. http://www.mobot.org/MOBOT/research/APweb/

Sun Y, Fan Z, Li X, Liu Z, Li J, Yin H. 2014. Distinct double flower varieties in Camellia japonica exhibit both expansion and contraction of C-class gene expression. BMC Plant Biology 14: 288.

Tamura M. 1993. Ranunculaceae. In: Kubitzki K, Rohwer JG, and Bittrich V, eds. The families and genera of vascular plants II. Berlin and Heidelberg: Springer.

Tepfer SS. 1953. Floral anatomy and ontogeny in Aquilegia formosa var. truncata and Ranunculus repens. University of California Publications in Botany 25: 513-648.

Tian XH, Zhao L, Ren Y, Zhang XH. 2007. Number of floral organs in Circaeaster agrestis (Circaeasteraceae) and possible homeosis among floral organs. Plant Systematics and Evolution 265: 259-265.

Theißen G, Saedler H. 2001. Floral quartets. Nature 409: 469-471.

Tucker SC, Hodges SA. 2005. Floral ontogeny of Aquilegia, Semiaquilegia, and Enemion (Ranunculaceae). International Journal of Plant Sciences 166: 557-574. Van der Niet T, Johnson SD. 2012. Phylogenetic evidence for pollinator-driven diversification of angiosperms. Trends in Ecology and Evolution 27: 353-361. Van Heel WA. 1981. A S.E.M.- investigation on the development of free carpels. Blumea 27: 499-522. 
Wang W, Lu AM, Ren Y, Endress ME, Chen ZD. 2009. Phylogeny and classification of Ranunculales: evidence from four molecular loci and morphological data. Perspectives in Plant Ecology, Evolution and Systematics 11: 81-110.

Wang P, Liao H, Zhang W, Yu X, Zhang R, Shan H, Duan X, Yao X, Kong H.

2015. Flexibility in the structure of spiral flowers and its underlying mechanisms.

Nature Plants 2: 1-10.

Wang W, Lin L, Xiang XG, Ortiz RDC, Liu Y, Xiang KL, Yu SX, Xing YW, Chen

ZD. 2016. The rise of angiosperm-dominated herbaceous floras: Insights from Ranunculaceae. Scientific Reports 6: 1-8.

Xu Y, Yamaguchi N, Gan E-S, Toshiro I. 2019. When to stop: an update on molecular mechanisms of floral meristem termination. Journal of Experimental Botany 70: $1711-1718$.

Zhai W, Duan X, Zhang R, Guo C, Li L, Xu G, Shan H, Kong H, Ren Y. 2019. Chloroplast genomic data provide new and robust insights into the phylogeny and evolution of the Ranunculaceae. Molecular Phylogenetics and Evolution 135: 12-21.

Zhang R, Guo C, Zhang W, Wang P, Lin L, Duan X, Du Q, Zhao L, Shan H, Hodges SA, Kramer EM, Ren Y, Kong H. 2013. Disruption of the petal identity gene APETALA3-3 is highly correlated with loss of petals within the buttercup family (Ranunculaceae). Proceedings of the National Academy of Sciences of the United States of America 110: 5074-5079 


\section{Figures}

Figure 1. Delphinium and Aquilegia studied cultivars. (A) Delphinium $\times$ Pacific 'Blue Jay'. (B) D. × Pacific 'Guinevere'. (C) D. × Pacific 'Galahad'. (D) D. × Pacific 'Astolat'. (E) D. × elatum 'Sky sensation'. (F) A. vulgaris 'Leprechaun Gold'. (G) A. vulgaris 'Nora Barlow'. (H) A. × hybrida 'Green Apples'. (I) Aquilegia $\times$ hybrida 'Ruby Port'. Flowers from the latter variety present a very short petal spur on each of the organs; spurs are not visible on the picture. All plants were provided by the Jardin du Pic Vert (www.jardindupicvert.com). A, C, D, E, F images are taken from living material; B, G, I images are taken from herbarium material.

Figure 2. Dissections of Delphinium $\times$ Pacific 'Blue Jay' and Aquilegia vulgaris 'Leprechaun Gold' flowers. (A, B) Dissection of one flower of each cultivar, taken as an example to show floral organization. A line indicates the pedicel, scale $=5 \mathrm{~mm}$. (A) Flower of $D . \times$ Pacific 'Blue Jay': s=sepals, $\mathrm{p}=$ petals; mosaic organs are indicated with an asterisk; parastichies of stamens are represented by dotted lines. The carpels are at the center of the flower. (B) Flower of $A$. vulgaris 'Leprechaun Gold': s=sepals, $\mathrm{p}=$ petals, mosaic organ is indicated by an asterisk. Orthostichies formed by the stamens are represented by dotted lines. Staminodes and carpels are arranged in whorls at the center of the flower.

Figure 3. Floral vascularization of Delphinium $\times$ Pacific ‘Blue Jay' (A-E) and Aquilegia vulgaris 'Leprechaun Gold' (F-J). (A) Floral diagram of D. $\times$ Pacific 'Blue Jay': sepals (green and blue crescents, two colors were used to differentiate outer and inner sepals), petals (red crescents), stamens (pink dots), carpels (violet reniform shapes). (B) Vascularization of sepals: dorsal spurred organ supplied by three bundles, 
the other ones by two ramified bundles. (C) Vascularization of inner perianth organs: two dorsal spurred organs supplied by a single bundle; the other ones supplied by two bundles. The ventralmost organ is supplied by two bundles and by a ramification of a bundle of one ventral sepal (these organs may correspond to additional sepals). (D) Vascularization of the innermost perianth organs: each organ is supplied by a single bundle and the dorsalmost organs are spurred (they may correspond to petals). (E) Stamens and carpels are supplied by one and three bundles respectively. In this figure, the identity of the Delphinium perianth organs is hypothetical because the anatomical analysis was performed before anthesis, preventing us from observing the fully developed organs. (F) Floral diagram of A. vulgaris 'Leprechaun Gold': sepals (green crescents), petals (dark blue, light blue and violet crescents), stamens (beige dots), staminodes (red shapes), carpels (violet reniform shapes). (G) Stamens are supplied by three vascular bundles. (H) Each petal (in dark blue, light blue and violet) is supplied by a single vascular bundle. The origin of the bundles creates a sort of network between organs (bundles in violet to light blue). (I) Staminodes and stamens are supplied by a single bundle each. (J) Carpels are supplied by three bundles. (K-L) Cross-sections of the corolla of the flower bud of Delphinium $\times$ Pacific 'Blue Jay' and Aquilegia vulgaris 'Leprechaun Gold. Arrows point the origin of the vascular traces of some supernumerary petals; s: sepal (numbered following the order of initiation); petals are indicated with asterisks; scale $=1 \mathrm{~mm}$.

Figure 4. Mosaic organs of Delphinium $\times$ Pacific 'Blue Jay' and their position within the flower. (A1 and B1) One of the mosaic organs found among carpels. These organs look like open carpels with naked ovules (indicated with stars). They present abnormal structures looking like anthers (dotted line in A1) and winged extensions (plus signs in 
A1, B1). (C1) One of the mosaic organs found surrounding the carpels. These organs present structures that look like anthers (dotted line) and outgrowths similar to naked ovules. (D1) One of the mosaic organs surrounding typical stamens. Some of these organs present an anther-like structure with a petaloid extension at the apex (plus sign), scale $=1 \mathrm{~mm} .(\mathrm{A} 2, \mathrm{~B} 2, \mathrm{C} 2, \mathrm{D} 2)$ Floral diagram of $D . \times$ Pacific 'Blue Jay', asterisks indicate the position of these abnormal organs within the flower.

Figure 5. Wild-type (WT) and mutant flower morphologies in Delphinium and Aquilegia and summary of the different combinations of character states that were observed in flowers of all the varieties investigated. (A) Schematic representation of the Delphinium WT flower. The pair of dorsal spurs of the ventrally-reduced corolla is nested in the spur of the calyx. (B) All possible character states (Arabic numbers) for each organ category (Roman numbers) in Delphinium floral mutants. When spurs are present, their number is specified. In I.3 for instance, the calyx can bear a single spur (nested in the spur of another dorsal sepal), or a pair of spurs (nested in one or two outer spurs of the calyx). (C) Table, to be read vertically, synthesizing the combinations of character states observed in Delphinium cultivars. The three sets of character state combinations found in Delphinium $\times$ Pacific 'Blue Jay' are indicated with three pink dotted lines. (D) Schematic representation of the Aquilegia WT flower. The corolla consists of 5 spurred petals. (E) All possible character states (Arabic numbers) for each organ category (Roman numbers) in Aquilegia floral mutants. When spurs are present, their number is specified. (F) Table, to be read vertically, synthesizing the combinations of character states observed in Aquilegia cultivars. The sets of character state combinations found in Aquilegia vulgaris 'Leprechaun Gold' are found within the rectangle with the pink dotted sides. 
Calyx, corolla, androecium, and gynoecium are colored in dark blue, light blue, orange, and green, respectively. The sets of staminodes and of mosaic organs are shown in purple and with a gradient between the colors of the organ identities involved. Roman and Arabic numbers refer to organ categories and state within each category, respectively. The absence of a certain category of floral organs is shown with a circled cross. The thickness of the circles and the diameter of the disks indicate whether the number of organs within each category is larger, equal, or smaller than in the WT. The phyllotaxis (spiral or whorled) of each organ category is indicated at the right of each drawing.

Figure 6. SEM micrographs of the floral developmental sequence of Delphinium $\times$ Pacific 'Blue Jay'. (A) Quincuncial development of sepals, scale $=100 \mu \mathrm{m}$. (B) Before the establishment of zygomorphy, all primordia begin their differentiation on the floral dome. At this stage there is no delay in the development of any of the organs, scale $=$ $200 \mu \mathrm{m}$. (C) Spirally inserted primordia producing parastichies on the floral dome (dotted arrows), scale $=200 \mu \mathrm{m}$. (D) Before the carpels (asterisks) are fully developed, a set of undifferentiated cells remains at the top of the meristem (arrow), scale $=500$ $\mu \mathrm{m}$. (E) When organ differentiation is completed, the development of spurs begins (arrow), scale $=500 \mu \mathrm{m}$. (F) In horticultural flowers like in WT flowers, zygomorphy is established by the irregular development of perianth organs (arrows point to primordia with an arrested development), and by the development of spurs (highlighted with the dotted line), scale $=1 \mathrm{~mm}$. Abbreviations: s: sepal (numbered following the order of initiation), fd: floral dome, br: bracteoles, p: perianth organs (sepals or petals), *: carpels. 
Figure 7. Mosaic organs of Aquilegia vulgaris 'Leprechaun Gold' and their position within the flower. (A, C) Mosaic organs presenting a spur-like structure (dotted line) and an anther-like structure (dotted line with squares), scale $=0,5 \mathrm{~mm}$. The organ is fixed to the floral receptacle by a filament-like structure (dotted line with circles). (B) Floral diagram of $A$. vulgaris 'Leprechaun Gold', asterisks indicate the localization of these type of mosaic organs within the flower.

Figure 8. SEM micrographs of the floral developmental sequence of Aquilegia vulgaris 'Leprechaun Gold'. (A) Sepal quincuncial development, scale $=50 \mu \mathrm{m}$. (B) Whorled organogenesis of petals and stamens (dotted arrow showing the direction in which the differentiation of the organs occurs on the orthostichy), scale $=100 \mu \mathrm{m}$. (C) During carpel differentiation (arrow), there is no clear differentiation among supernumerary petals, and stamens or staminodes within the orthostichies (the line shows one orthostichy); only outer petal primordia begin to expand and flatten (dotted line shows one flattened organ), scale $=100 \mu \mathrm{m}$. (D) Once all organs are differentiated, the difference in thickness and size of petals and the rest of the organs on the orthostichy becomes obvious, perianth whorls are recognizable (arrows point to flattened organs at the base of the orthostichies; line showing an orthostichy), scale $=200 \mu \mathrm{m}$. (E, F) Petal spurs start to develop once floral organogenesis is completed. Successive whorls of petals are alternate (arrows point to developing spurs), scale $=500 \mu \mathrm{m}$ and $1 \mathrm{~mm}$ respectively. Abbreviations: br: bracteoles, fd: floral dome, s: sepals (numbered following the order of initiation), p: petals, st: stamens, ${ }^{*}$ : staminodes, cp: carpels.

Figure 9. SEM micrographs of a floral bud and an abnormal organ of Aquilegia $\times$ hybrida 'Green Apples'. (A) Lateral view of a bud (with some perianth organs removed 
in order to show the different floral organs): sepals= green, petals= blue, mosaic organs $=$ violet, stamens $=$ orange, carpels $=$ red; scale $=0,5 \mathrm{~mm}$. (B) Inner view of a mosaic organ: arrows point at structures looking like pollens sacs, the asterisk indicates a petaloid extension at the apex of the organ. A filament-like structure is found at the base of the organ; scale $=0.5 \mathrm{~mm}$.

\section{Supplementary data}

Table 1 S1 General number of perianth organs in Delphinium and Aquilegia cultivars flowers used in this study.

The herbarium code corresponds to a representative specimen of each cultivar deposited at the Paris Herbarium $(\mathrm{P}$;

https://science.mnhn.fr/institution/mnhncollection/p/item/search/form). 
Figure 1.

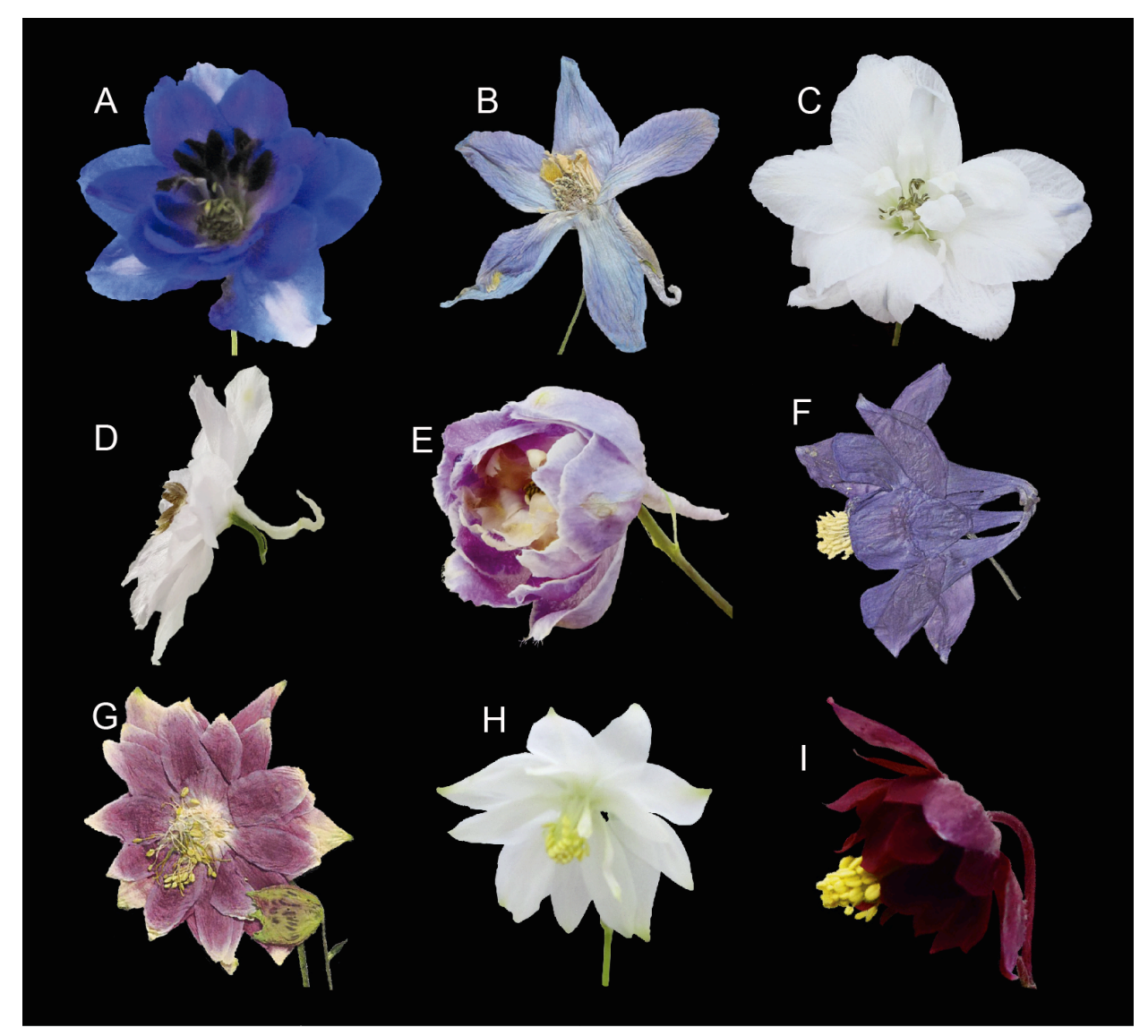

Figure 2.

A

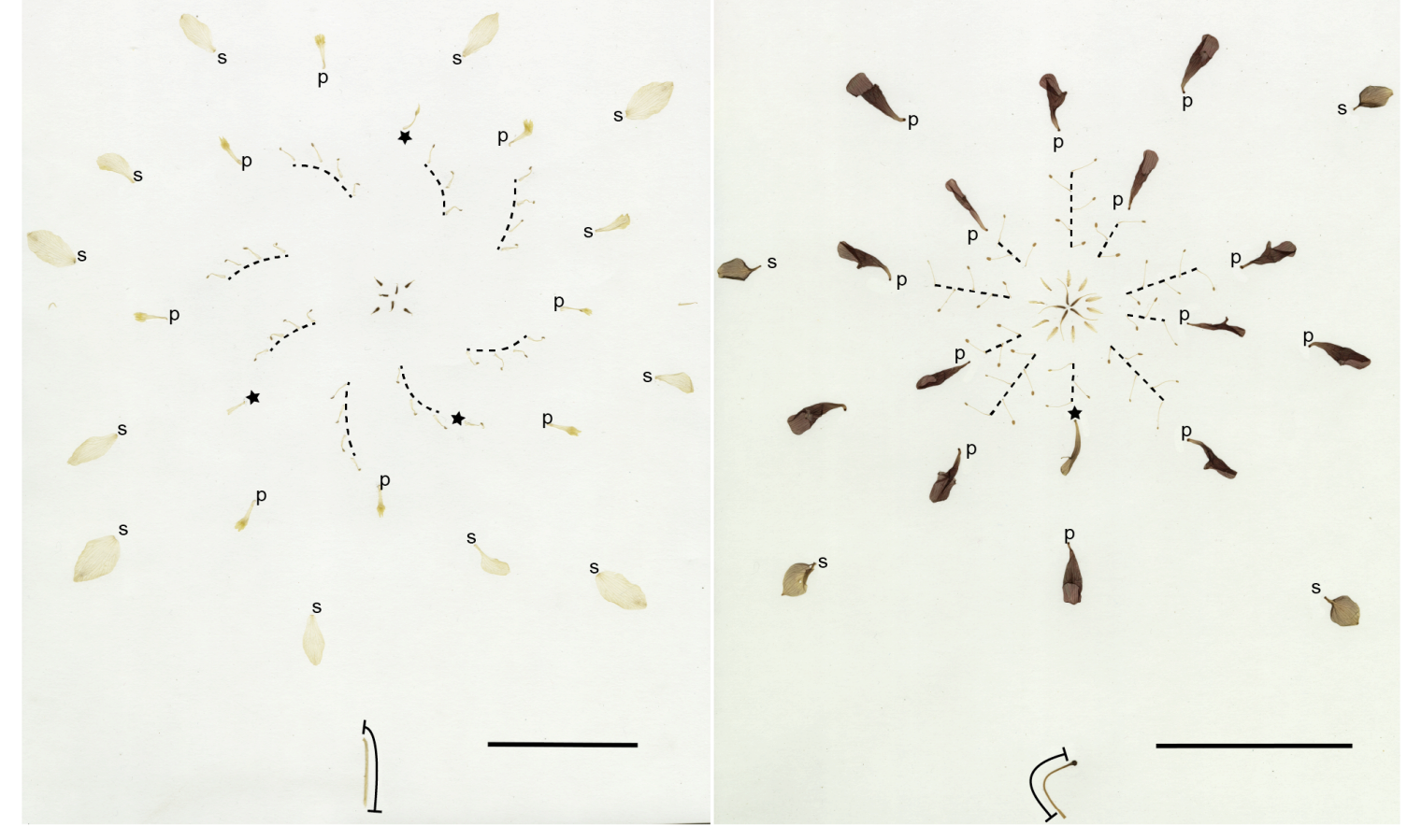


Figure 3.

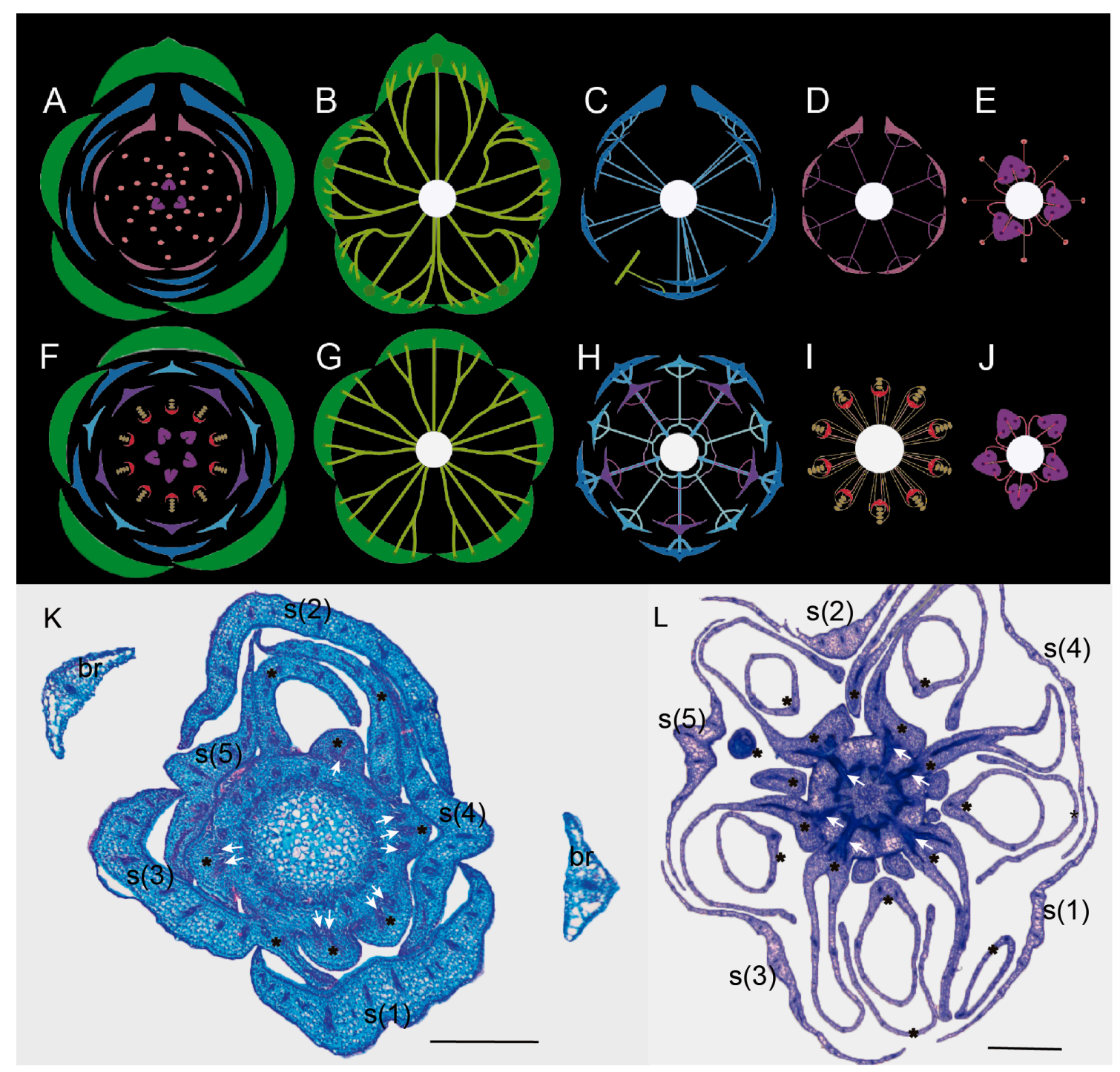


Figure 4.

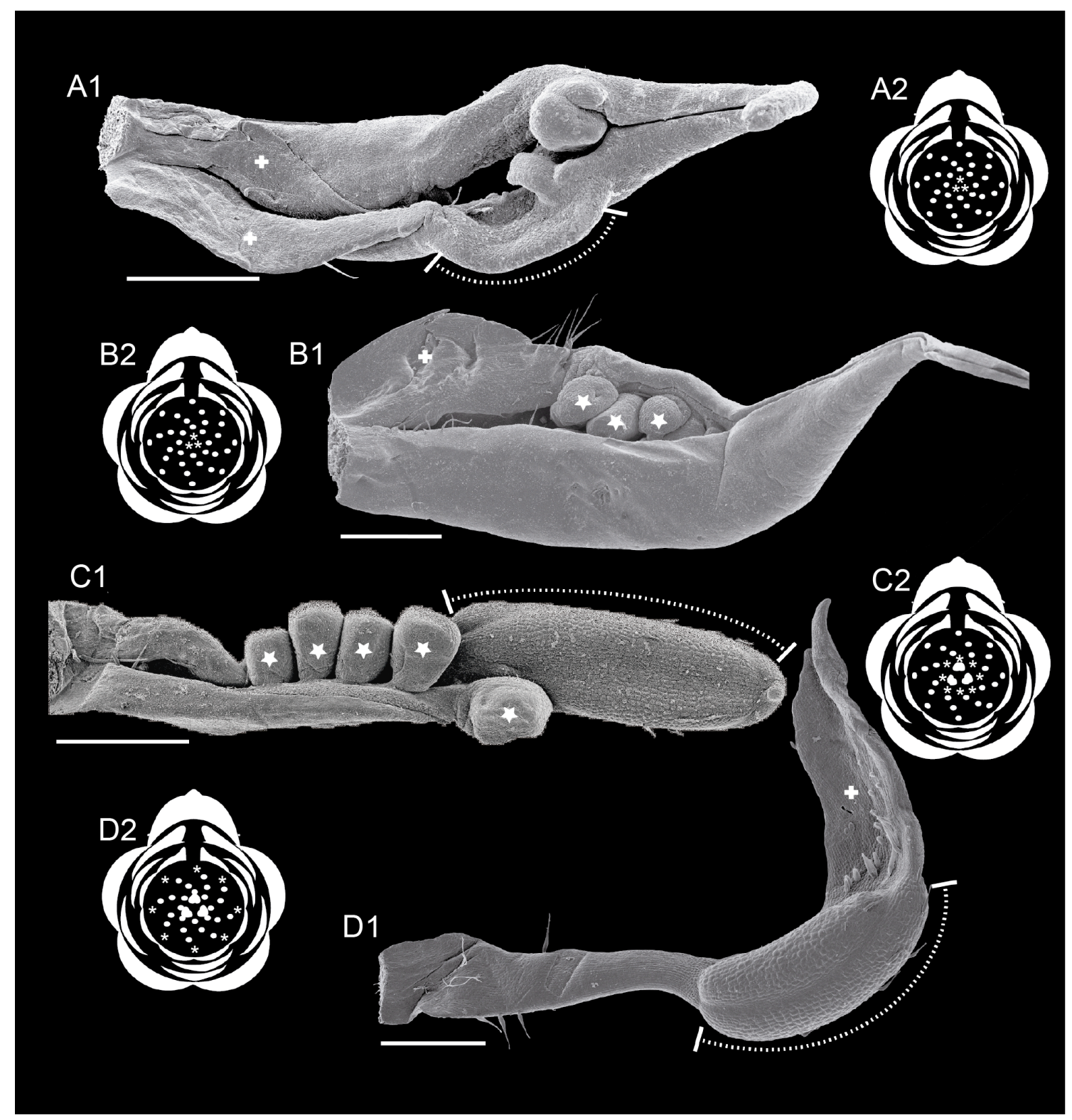


Figure 5.
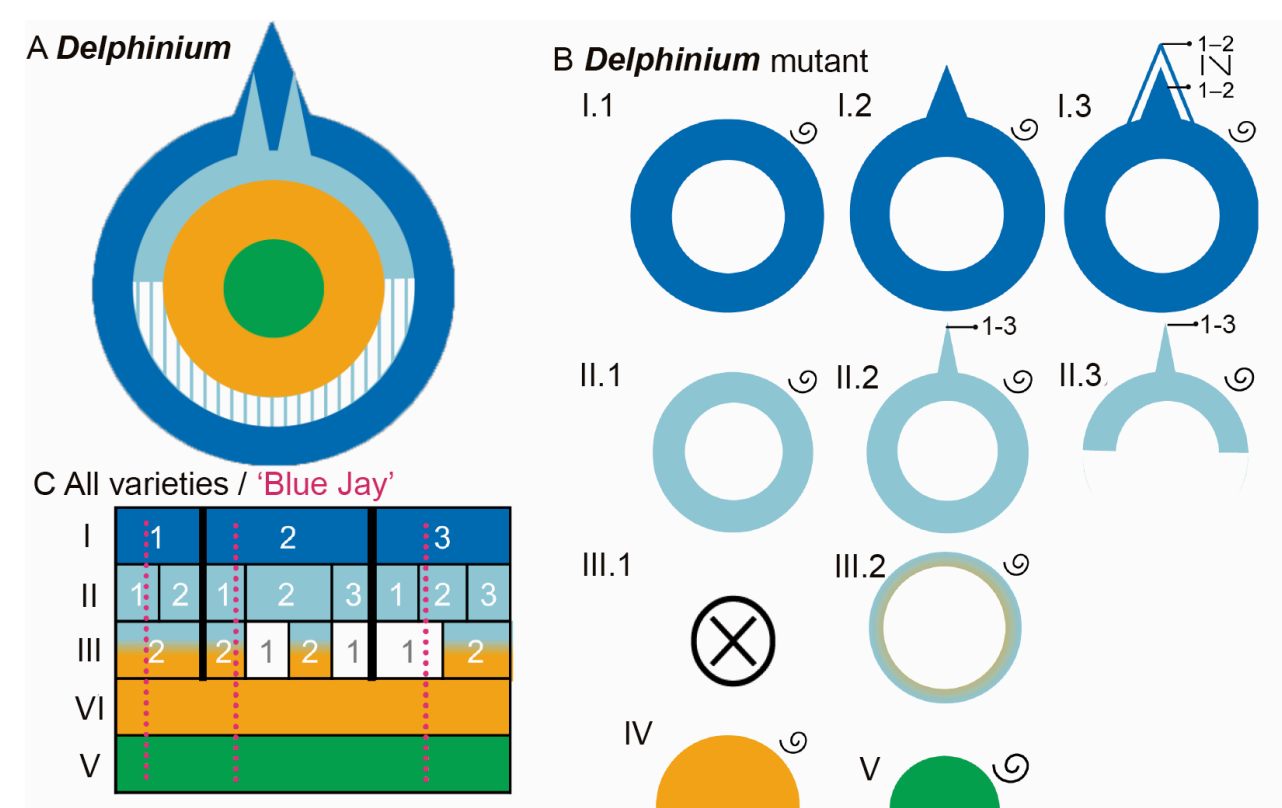

III. 1
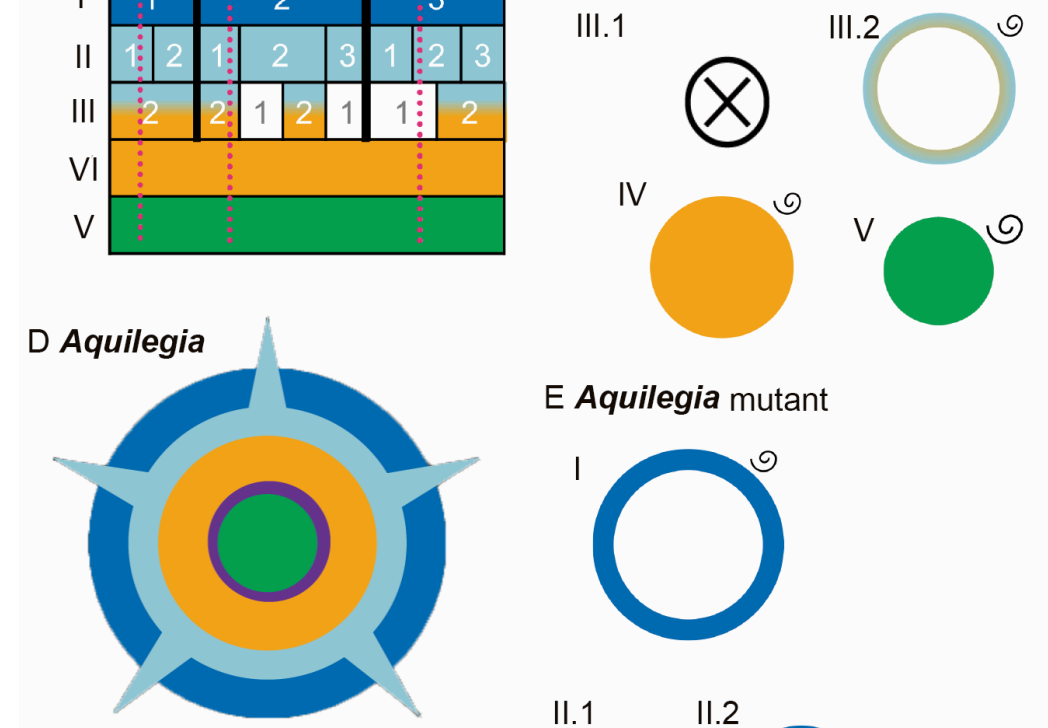

IV.1 IV.2

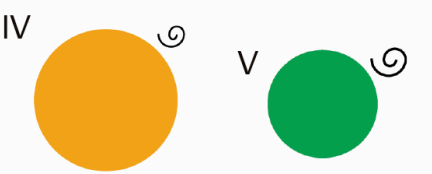

E Aquilegia mutant

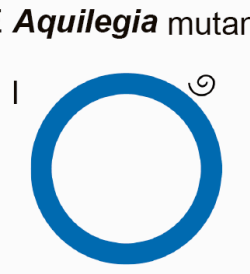

F All varieties / 'Leprechaun Gold'

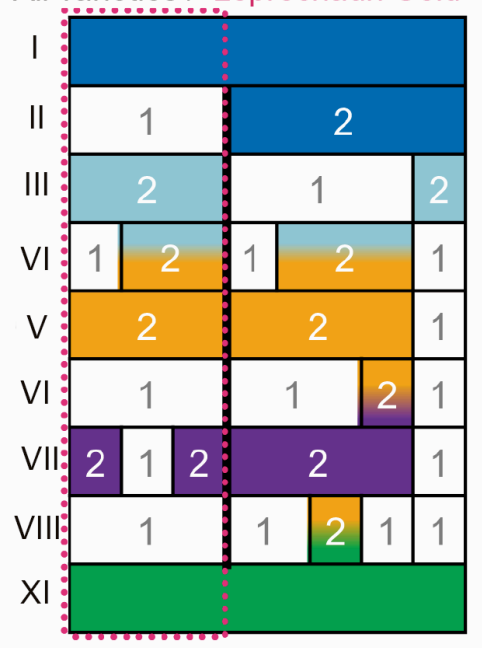

Х)

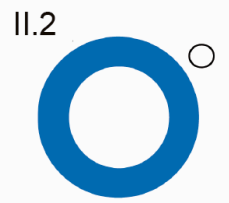

$\otimes$

V.1

Q

V.2

VI.1

凶)

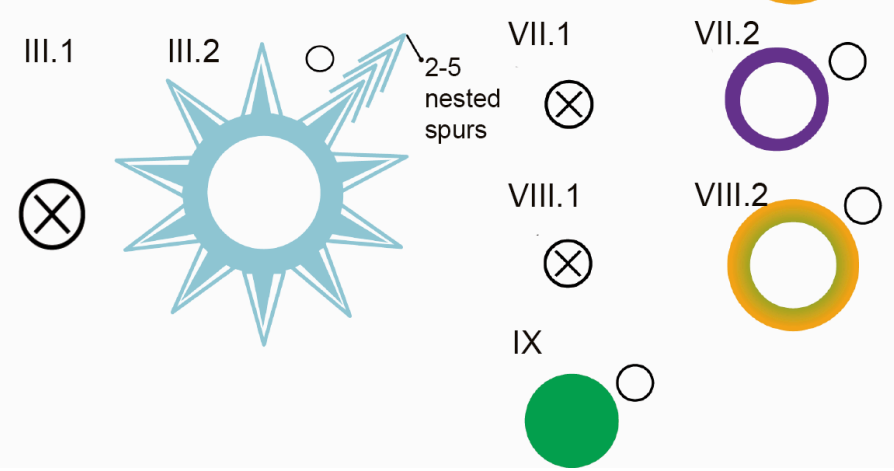


Figure 6.

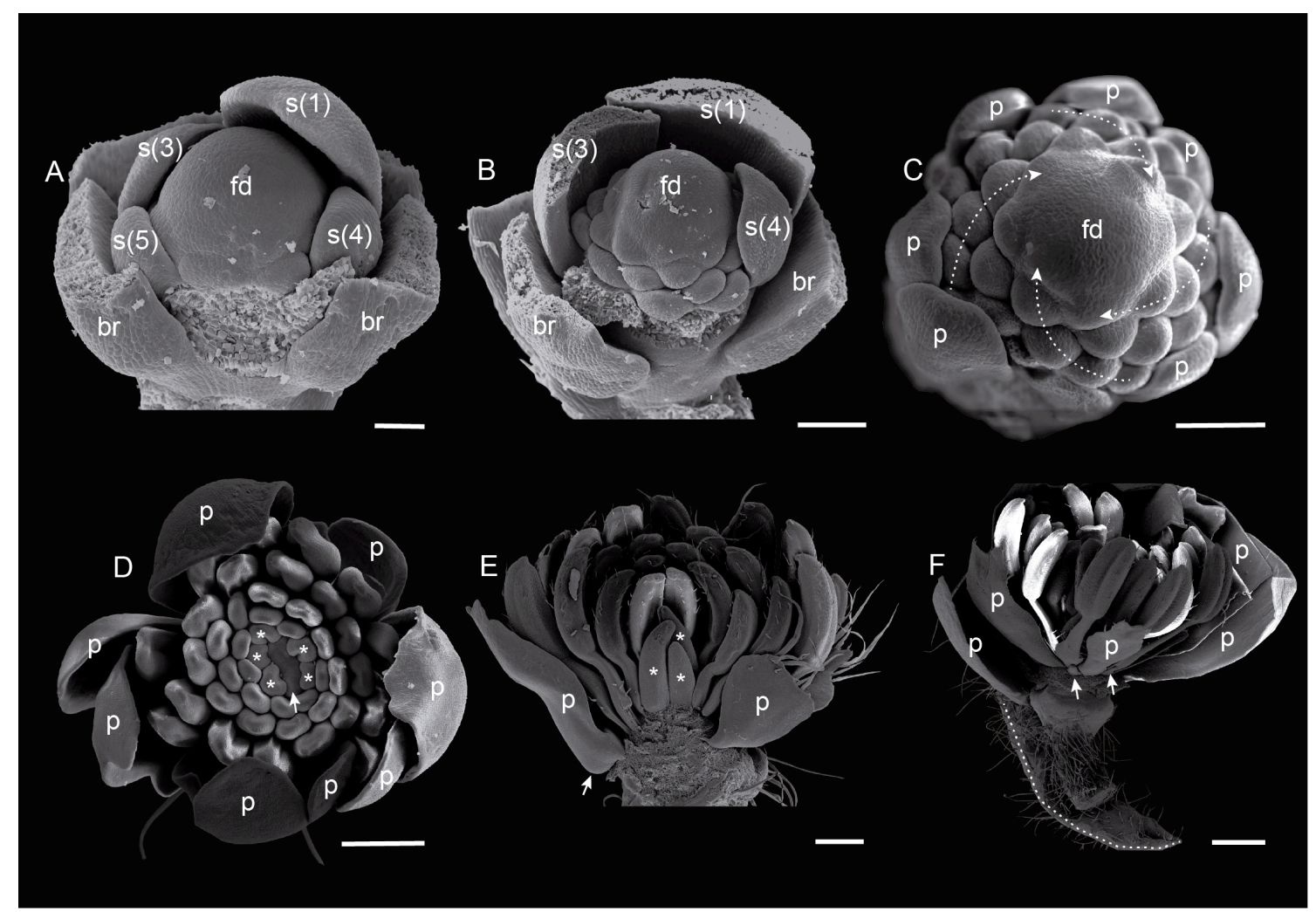

Figure 7.

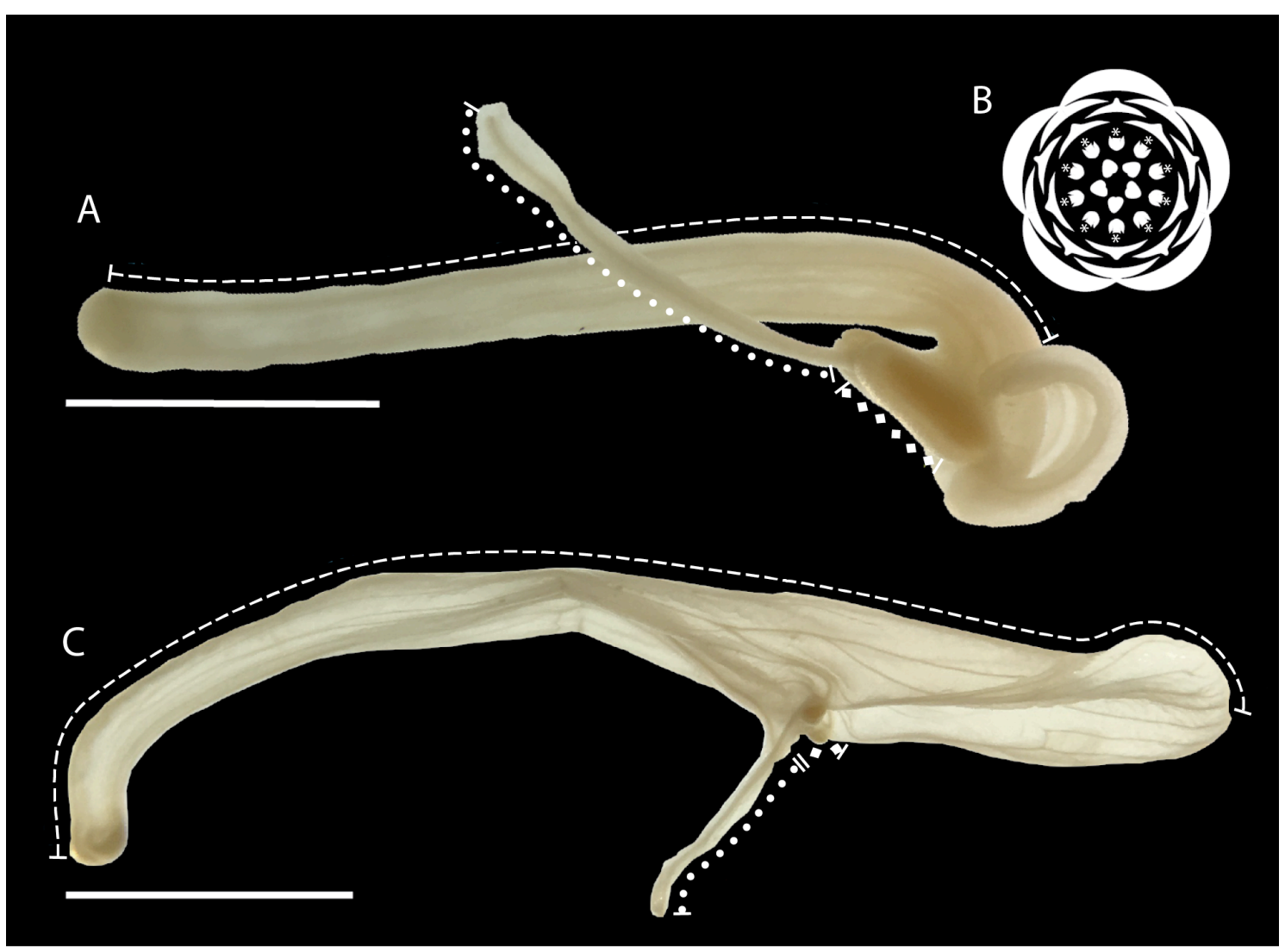


Figure 8.

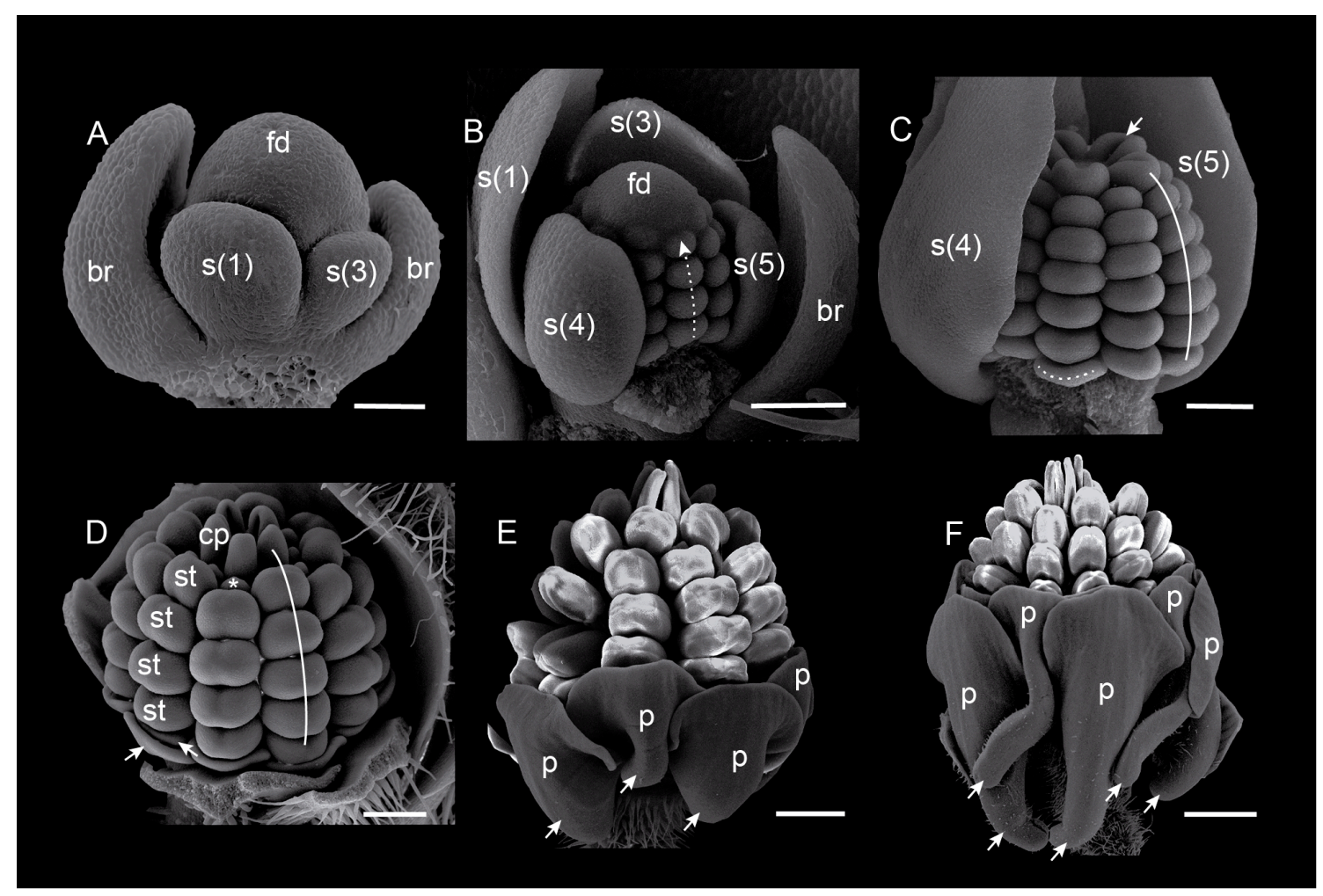

Figure 9.

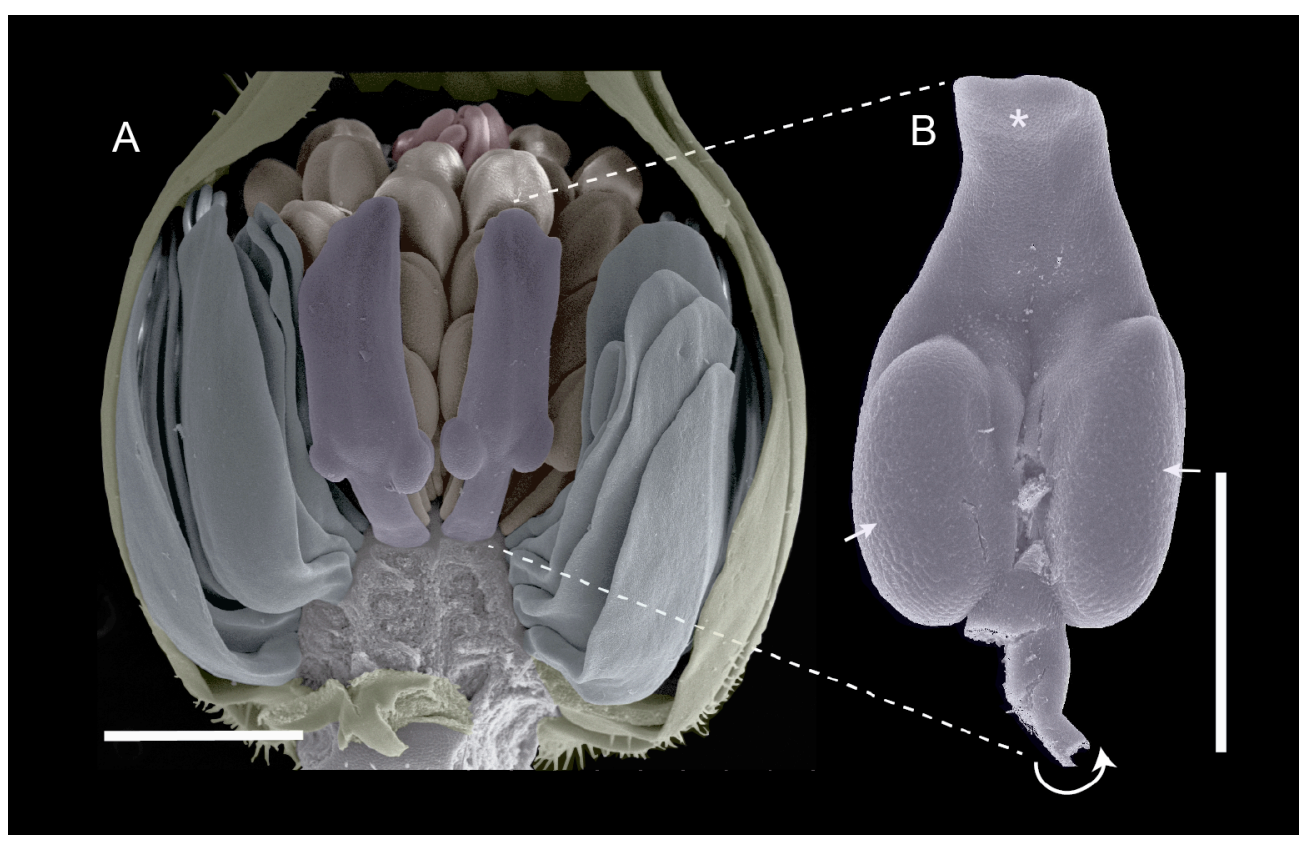

